\title{
A Review on the Nutritional Quality and Medicinal Value of Custard Apple-An Under Utilised Crop of Madhya Pradesh, India
}

\author{
Reena Nair and Vijay Agrawal* \\ Department of Horticulture, JNKVV, Jabalpur (M.P.), India \\ *Corresponding author
}

\begin{tabular}{|l|l}
\hline \multicolumn{1}{l}{} & \multicolumn{1}{c}{ A B S T R A C T } \\
\cline { 2 - 2 } $\begin{array}{l}\text { Keywords } \\
\begin{array}{l}\text { Madhya Pradesh. } \\
\text { Nutritional value, } \\
\text { Medicinal value, } \\
\text { Malnutrition. }\end{array}\end{array}$ & $\begin{array}{l}\text { Custard apple is one of the most delicious arid fruits known mostly for its } \\
\text { dessert and confectionery values. Annona squamosa, which is one of the } \\
\text { most widely grown species of Annona. Though rich in its nutritional } \\
\text { aspects, it is an under-utilized arid zone crop. It has also been proved that } \\
\text { the plant contains several medicinal properties which include antioxidant, } \\
\text { anti-diabetic, anti-infective and anti dyslipidemic properties. The leaves are } \\
\text { used as a vermicide, for treating cancerous tumors and are applied to } \\
\text { abscesses, insect bites and other skin complaints. Scrapings of root-bark are }\end{array}$ \\
\cline { 1 - 1 } $\begin{array}{l}\text { Accepted: } \\
\text { 17 July 2017 } \\
\text { Available Online: }\end{array}$ 10 September 2017 & $\begin{array}{l}\text { used for toothache. This paper attempts to congregate the nutritional value, } \\
\text { phytochemical composition, and medicinal uses of custard apple. }\end{array}$ \\
\hline \hline
\end{tabular}

Introduction

Agriculture sector in Madhya Pradesh forms the backbone of its economy. Madhya Pradesh, with its large area, enjoys diverse climatic and soil conditions suitable for a broad range of agricultural products. It contributes almost one-fourth of the Gross State Domestic Product (GSDP) and is the main source of employment for over 70 percent of the population and constitutes about 60- 75 percent of the rural income. There are many herbs, shrubs and trees, which have significant economic uses and are nutritious but are under severe neglect. Cultivation of some of these species is restricted to a small region in spite of their potential to grow in other regions. The major custard apple growing districts in Madhya
Pradesh is depicted in figure 1. According to [1], even though India has made significant progress in food production, disease control, and economic and social development since independence, it still accounts for 40 per cent of the world's malnourished children and about 60 per cent of Indian women are anemic. Likewise, as per the report on malnutrition in the Times of India Jan 25, 2016, Madhya Pradesh has been registered the highest infant mortality rates in the country for almost a decade and currently 51 infants out of 1000 doesn't even celebrate their first birthday. This is followed by Bihar (48), Uttarakhand (40), and Haryana (33). The latest report of NFHS-4 [2] revealed that 40 out of 100 children are malnourished in M.P. 
A voluntary organisation Child Rights and You (CRY) stated that more than $40 \%$ children under the age of 5 are stunted (low height for weight) while $42.8 \%$ children below 5 are underweight. The percentage of children who are wasted (low weight for age) has come down from 35 to $25.8 \%$ but the number is still considered very high by WHO standards. There is wide diversity of several underutilized fruit trees in the state which are highly nutritious and can help to fight against malnutrition. One of them is custard apple, which is one of the most drought tolerant fruit trees in India and can be grown in rocky soils. This luscious and nutritious fruit is eaten throughout the world.

Custard apple (Annona squamosa L.) is one of the most important delicious arid fruits known mostly for its dessert and confectionery values. It belongs to the family Annonaceae of the order Magnoliales [3]. The genus name, 'Annona' is from the Latin word 'anon', which means 'yearly produce'. Annona cherimola and Annona reticulate are the other related species. It is also known as sharifa, sitaphal and sugar apple. The fruit has pleasant texture and flavour and is sweet with slight acidity. It is a subtropical small deciduous spreading tree of height 5-9 feet, with large green dropping leaves and light yellow trumpet shaped flowers, emitting pungent sweet smell during late afternoon. It starts bearing at the age of 4 to 6 years and the bearing declines after 12 to 15 years. Being rich in carbohydrate $(23.0 \mathrm{~g} / 100 \mathrm{~g})$ and possessing pleasant flavour, custard apple fruits are utilized for ice cream. Sitaphal is comparatively high calorie fruit and thus is included in diet for weight gain and athletes.

It gives $104 \mathrm{kcal}$ per $100 \mathrm{~g}$ of edible portion [4]. Custard apple prefers dry climate. It can withstand mild frost. The root system is confined to relatively shallow layers and therefore, these do not require deep soils.
However, it needs well-drained soil. The trees withstand high amounts of lime found in calcareous soils. The present review paper is an attempt to congregate the nutritional value, phytochemical composition, traditional uses, and other literature on Custard apple as a potential crop for the management of chronic disease and especially to combat malnutrition in the state of Madhya Pradesh. The fruit has pleasant texture and flavour and is sweet with slight acidity. Food value lies mainly due to sugar content which is about 12.4-18.15 per cent and protein 1.6 per cent [5].

\section{Nutritive value of custard apple}

Custard apples are usually consumed as dessert fruit. The nutritive value of custard apple per $100 \mathrm{~g}$ of pulp is presented in table 1 . The fruit is rich in starch when firm but increases markedly in sugar as it softens. The main sugars are glucose and fructose (80$90 \%)$. The calorific value is high $(300-450 \mathrm{~kJ}$ per $100 \mathrm{~g}$ ) and is almost double that of peach, orange and apple [6]. Custard apple is full of vitamin $\mathrm{C}$ anti-oxidants, which helps to combat many diseases and also enhances the immune system. It is abundant source of dietary fibre, Vitamin A, Vitamin C, Antioxidant, Potassium, magnesium and also contains calcium, Vitamin B6, Copper and Low fat levels, excellent source of Iron [7]. It has high calorific value, able to provide sustained energy and delicious in nature. It has about $3.1 \%$ of fibre in the edible portion.

Anti-oxidants like Vitamin C, present in the fruit helps to fight free radicals in our body. These are also rich in potassium and magnesium that protect us from cardiac diseases and blood pressure. The advantage of this fruit is that it is easily digestible even at old ages. Potassium in the sweet fruits makes active and removes the lethargies. It also helps to fight muscle weakness. It also contain Vitamin A, which keeps your skin 
and hair healthy, very important for the eyes, and cures indigestion. It should be included in our diet, as the copper content helps to cure constipation. As the fruit is high in magnesium, it maintains the water balance in our body, which helps in removing acids from the joints and reduces the symptoms of rheumatism and arthritis [8].

The physico-chemical analysis of custard apple was studied to assess the importance of custard apple in food and beverages [5]. They reported that pulp was source of carbohydrates 23.9 per cent and good source of protein 1.6 per cent. Juice of custard apple was used to improve the quality of custard apple carbonated beverages. The nutritive value of custard apple carbonated beverages shows that it was good source of carbohydrates $(12.9 \%)$, protein $(0.7 \%)$, fat $(0.18 \%)$. It was superior to other synthetic drinks. Custard apple contains natural sugar, and hence makes a great nutritious snack and can even be added to desserts especially for children. The fruit is comparatively high calorie fruit and thus is included in diet for weight gain and athletes. It gives $104 \mathrm{kcal}$ per $100 \mathrm{~g}$ of edible portion.

Fig.1 Major Custard Apple growing districts of Madhya Pradesh

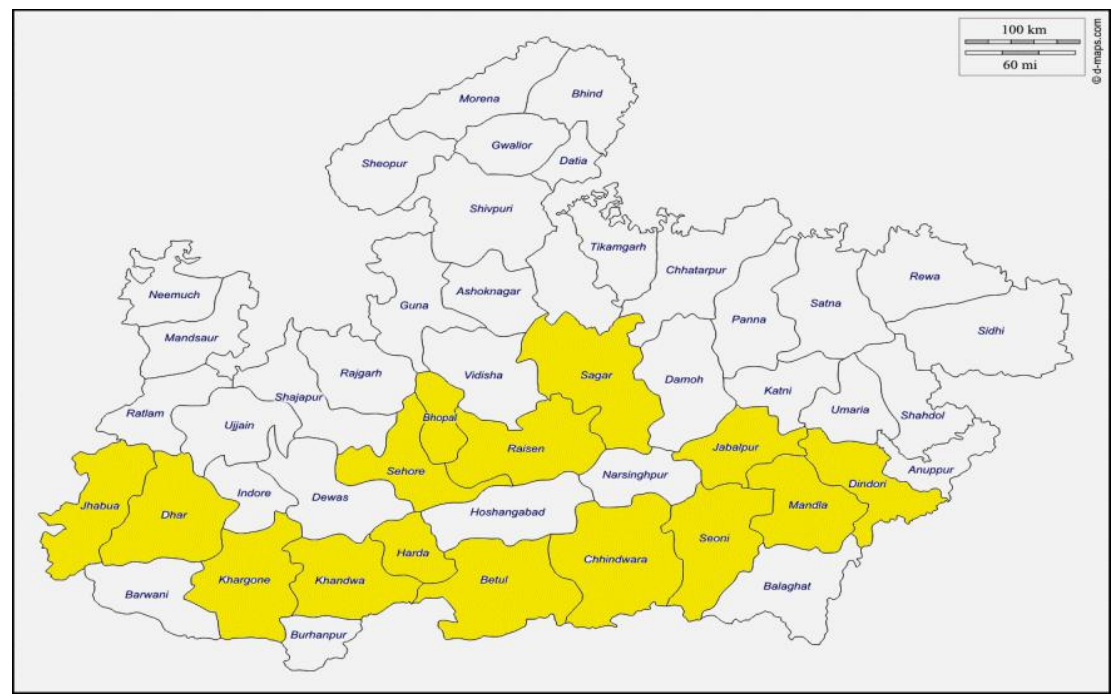

Fig.2 Compounds isolated from the bark of Annona squamosa

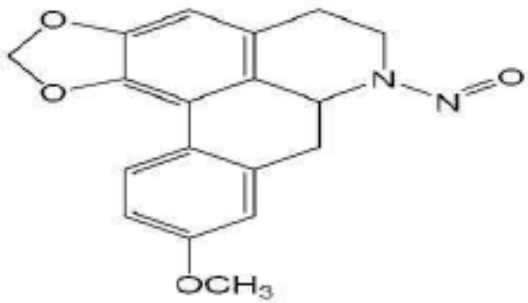

a. N-Nitrosoxylopine

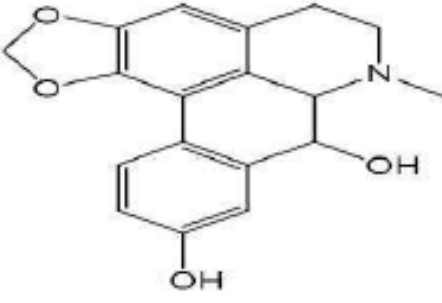

b. Roemerolidine

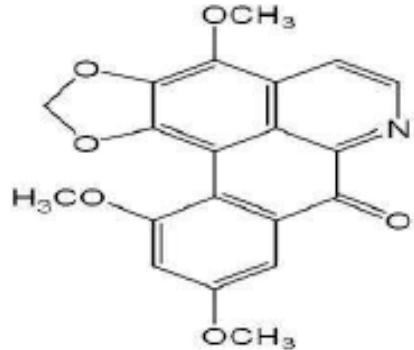

c. Duguevalline 
Table.1 Nutrient value of custard apple per $100 \mathrm{~g}$ of pulp

\begin{tabular}{|l|c|}
\hline Nutrient & Amount \\
\hline Water & $70-80 \%$ \\
\hline Protein & $5.2 \mathrm{~g}$ \\
\hline Ash & $1.9 \mathrm{~g}$ \\
\hline Calories total & 235 \\
\hline Carbohydrate cals. & 213 \\
\hline Fat calories & 6.1 \\
\hline Protein calories & 17 \\
\hline Total carbohydrate & $59 \mathrm{~g}$ \\
\hline Dietary fibre & $11 \mathrm{~g}$ \\
\hline Total fat & $725 \mathrm{mg}$ \\
\hline Saturated fat & $120 \mathrm{mg}$ \\
\hline Mono-saturated fat & $285 \mathrm{mg}$ \\
\hline Poly unsaturated fat & $100 \mathrm{mg}$ \\
\hline Omega-6fatty acids & $100 \mathrm{mg}$ \\
\hline Vitamin A & $15 \mathrm{I} . \mathrm{V}$. \\
\hline Vitamin C & $91 \mathrm{mg}$ \\
\hline Nutrient & \\
\hline Thiamine & $275 \mathrm{mcg}$ \\
\hline Riboflavin & $283 \mathrm{mcg}$ \\
\hline Niacin & $2.2 \mathrm{mg}$ \\
\hline Vitamin B6 & $500 \mathrm{mcg}$ \\
\hline Folate & $35 \mathrm{mcg}$ \\
\hline Pantothenic acid & $565 \mathrm{mcg}$ \\
\hline Calcium & $60 \mathrm{mg}$ \\
\hline Iron & $105 \mathrm{mg}$ \\
\hline Magnesium & $53 \mathrm{mg}$ \\
\hline Phosphorus & $80 \mathrm{mg}$ \\
\hline Potassium & $618 \mathrm{mg}$ \\
\hline Sodium & $23 \mathrm{mg}$ \\
\hline Zinc & $250 \mathrm{mcg}$ \\
\hline Copper & $215 \mathrm{mcg}$ \\
\hline Selenium & $1.5 \mathrm{mcg}$ \\
\hline
\end{tabular}

Source: [Kokate, 2014]

\section{Medicinal value of custard apple}

The health and medicinal benefits of the Custard apple fruit are numerous and it appears to possess potent bioactive principles in most of its plant parts (fruit, seed and leaves). The various chemical constituents isolated from leaves, stems, and roots of the plant include anonaine, aporphine, coryeline, isocorydine, norcorydine, and glaucine [10]. For centuries, Ayurvedic practitioners in India have extensively use various parts of the sugar apple (Annona squamosa) tree for the management of diabetes. Essential oils, pinenes have also been described and extracted from custard apple [11]. One class 
of chemicals which sets custard apple apart from other fruit species is the presence of acetogenins [12]. The acetogenins are unique to the Annonaceous family, which are very long chain fatty acids, and only found in Annonaceous species. The in vitro and in vivo studies appear to have considerable anticancer properties and anti-hypertensive properties.

The anti-cancer properties of custard apple appear to be mainly due to a class of compounds called acetogenins which are specific to Annonaceaous species. Acetogenins have been tested in vitro against 60 types of cancer cells, including breast, prostate and colon. Compared with paclitaxel a standard anti-cancer drug, bullatacin, an acetogenin, was 300 times as potent even at in vivo test system. Custard apple has been used for treatment of malaria. Three known aporphine alkaloids were isolated from the bark. Structures of compounds were identified as N-Nitrosoxylopine, Roemerolidine and Duguevalline (Fig. 2). All the three antimalarial alkaloids exhibit moderate activity against chloroquine sensitive strain (D10) and a chloroquine resistant strain (Dd2) of Plasmodium falciparum [13].

Despite its high sugar content the glycemic index of custard apple is low (i.e. 54). The fruit has antioxidant activity making it suitable even for diabetic patients [4]. In antidiabetic studies on animals, custard apple appears to mimic insulin stimulating its production and enhanced uptake of glucose by muscles which leads to stabilization of blood sugar concentrations. In fact, even leaf extracts are also effective in lowering blood glucose levels and several reports indicates that Annona squamosa leaf extract can substitute effectively with decreased doses of externally administered insulin. [14]

The fruit of Annona spp. have been shown to have anti-microbial activities due to several compounds which include Ent-kauranes, Acetogenins, essential oils and Benzylisoquinolines alkaloids [15]. Two acetogenins, annoreticuin and isoannoreticuin isolated from the leaves, were found to be selectively cytotoxic to certain human tumours. It also possesses Anti HIV properties. Among the 14 isolated compounds in a study, 16, 17-dihydroxy-entkauran-19-oic acid showed significant activity against HIV replication [16] in $\mathrm{H} 9$ lymphocyte cells with an EC50 value of $0.8 \mu \mathrm{g} / \mathrm{Ml}$.

Realizing the advantages of these species, serious attempts have to be made to popularize the cultivation of underutilized plants. Among them, a few species have performed exceedingly well by competing even with traditionally grown local crops and have provided sustainable income to farmers. Even though there are a lot of medicinal values for this fruit, the consumption and movement in the market is less. It is also established fact that seasonal, locally available, and cheap fruits and vegetables can also keep the population healthy and nutritionally secure rather than costly offseason ones. For longer-term use and sustainability, food production systems need to be linked with local initiatives.

To increase nutritional value and accelerate the value addition of custard apple several products have been prepared viz., ice cream, carbonated beverages smoothies, cheese cakes etc. The fruit pulp has shown numerous medicinal properties which include antioxidant, anti-diabetic, anti-infective and anti dyslipidemic properties. It is the fruit of $21^{\text {st }}$ Century, still the pulp of the fruit is not very easy for intake. There are a variety of recipes to overcome this problem and increase intake. There should be resurgence of intake of this fruit especially in the wake of increased percentage of diseases due to improper dietary habits and to reduce malnutrition. 


\section{References}

Banga, O., Petiet, J. and Van Bennekom, J. L. 1964. Genetical analysis of male sterility in carrots, Daucus carota L. Euphytica 13: 75-93.

Bannerot, H., Boulidard, L., Cauderon, Y. and Temp, J. 1974. Transfer of cytoplasmic male sterility from Raphanus sativus to Brassica oleraceae. In: Proc. Eucarpia Meet. Cruciferae, Scott. Hort. Res. Inst., Dundee. Pp.52-54.

De LC and Bhattacharjee SK. 2011. Handbook of Vegetable Crops. Pointer Publisher, Jaipur. Pp.76-81.

Dickson, M. H. 1975. G1117A, G1102A and G1106A cytosterile broccoli inbreds. HortScience 10: 535.

Geng, S. S., Chen, B. and Zhang, X.F. 2005. A new hot pepper F1 hybrid "Jingla No. 2". China Veg. 10/11: 41-42.

Hansche, P. E. and Gabelman, W. H. 1963. Digenic control of male sterility in carrots, Daucus carota L. Crop Sci. 3: 383-386.

Hoser- Krauze, J. and Antosik, J. 1987. Horticultural value and seed setting of cytoplasmic male sterile cauliflower line with Raphanus sativus CMS (Bannerot). Eucarpia Cruciferae Newsl. 12: 34 .

Hundal, J. S. and Khurana, D. S. 1993. 'CH1'-A new hybrid of chilli. Prog. Fmg. 29: 11-13.

Hundal, J. S. and Khurana, D. S. 2001. A new hybrid of chilli 'CH-3'- Suitable for processing. J. Res. Punjab agric. Univ. 39 (2): 326.

IIVR (Indian Institute of Vegetable Research) 2013. Vision 2050. Pp 1.

IARI (Indian Agriculture Research Institute) 2013. Annual report 2012-2013. Pp 19.

Johns, H. A. and Clarke, A. E. 1943. The story of hybrid onion. Proc. Am. Soc. Hort. Sci. 43: 189-194.

Jones, H. A. and Emsweller, S. L. 1936. A male sterile onion. Proc. Am. Soc. Hort. Sci. 63: 443.

Kalloo, G. 1988. Vegetable Breeding. Vol. I. CRC Press, Inc., Flordida. 23 p.

Kitagawa, J., Gerrath, J., Posluszny, U. and Wolyn, D. J. 1994. Developmental and morphological analysis of homeotic cytoplasmic male sterile and fertile carrot flowers. Sex. Plant Reprod. 7: 4150.

Kumar, S., Singh, V., Singh, M., Rai, S.K., Kumar, S., Rai, M. and Kalloo, G. 2007. Genetics and distribution of fertility restoration associated RAPD markers in pepper (Capsicum annuum L.). Hort. Sci. 111: 197-202.

Lal, T., Vashisht, V. and Dhillon, N. P. S. 2007. Punjab Anmol - A new hybrid of muskmelon (Cucumis melo L.). J. Res. Punjab agric. Univ. 44: 83.

Nandpuri, K. S., Singh, S. and Lal, T. 1982. 'Punjab Hybrid' a variety of muskmelon. Prog. Fmg. 18: 3-4.

Nieuwhof, M. 1961. Male sterility in brusselsprout, cauliflower and cabbage. Euphytica 10: 351-356.

Nieuwhof, M. 1990. Cytoplasmic-genetic male sterility in radish (Raphanus sativus L.), identification of maintainer, inheritance of male sterility and effect of environmental factors. Euphytica 47: 171-177.

Ogura, H. 1968. Studies of the male sterility in japanese radish with special referance to the utilisation of this sterility towards the practical raising of hybrid seeds. Meum. Fac. Agriculture, Kagoshima University. 6: 39-78.

Pearson, O. H. 1972. Cytoplasmically inherited male sterility characters and flavor component from the species Brassica napus. J. Am. Soc. Hort. Sci. 392-402.

Peterson, P. A. 1958. Cytoplasmically inherited male sterility in Capsicum. Am. Naturalist 92: 111-19. 
Singh, J. and Kaur, S. 1986. Present status of hot pepper breeding for multiple disease resistance in Punjab. Proceeding of VI EUCARPIA Meeting on Genetic and Breeding on Capsicum and Eggplant, Zaragoza (Spain). Pp.111-114.

Stanghellini, M. S., Ambrose, J. T. and Schultheis, J. R. 1998. Seed production in watermelon: A comparison between two commercially available pollinators. Hort- Science 33:28-30.

Watts, V. M. 1962. A marked male-sterile mutant in watermelon. Proc. Am. Soc. Hort. Sci. 81: 498-505.
Watts, V. M. 1967. Development of disease resistance and seed production in watermelon stocks carrying $m s g$ gene. J. Amer. Soc. Hort. Sci. 91: 579-580.

Walters, S. A. 2005. Honey bee pollination requirements for triploid watermelon. Hort Science 40:1268-1270.

Welch, J. E. and Grimball, E. L. 1947. Male sterility in the carrot. Sci. 106: 594.

Zhang, X. P., Skorupska, H. T. and Rhodes, B.B. 1994. Cytological expression in the male-sterile $m s$ mutant in watermelon. J. Hered. 85: 279-285.

\section{How to cite this article:}

Reena Nair and Vijay Agrawal. 2017. A Review on the Nutritional Quality and Medicinal Value of Custard Apple - An Under Utilised Crop of Madhya Pradesh, India. Int.J.Curr.Microbiol.App.Sci. 6(9): 1126-1132. doi: https://doi.org/10.20546/ijcmas.2017.609.135 